\title{
DETERMINATION OF TOTAL QUANTITY OF CELL WALL CONSTITUENTS IN FOODS AND FEEDS.
}

\author{
(Preliminary report.) \\ LaUri Paloheimo.
}

Zootechnical Institution, University Helsinki.

Received 15. III. 1945.

The defectivness of the so called Weende-method for determining of crude fibre is universally known. Altogether all attempts for replacing this method with a more accurate one have remained without success. The failure might be caused by the fact, that by the proposed new methods the most essential defects of the old method have not been corrected.

The writer's aim was to build up a method for determining the total quantity of plant cell wall constituents. The general principle by his method consists in dissolving the cell enclosure carbohydrates with very diluted acid. Before this procedure the matter should be extracted with ether. The remainder after the treating with acid consists of organic cell wall constituents together with some protein and ash. The protein content of the residue may be estimated as the difference of total crude protein of the matter and of the crude protein of the filtrate after the acid treatment. The total quantity of organic cell wall constituents is obtained as the difference: loss of ignition minus protein of the residue.

The main features of the treatment with diluted acid are as follows: $1-2$ grams of the sampl are put in a beaker with about 350 cc. cold water. The mixture is warmed up to boiling temperature. $20 \mathrm{cc}$. 1-normal $\mathrm{HCl}$ solution is added and the volume of solution completed to $400 \mathrm{cc}$. The duration of boiling should be 30 minutes. Evaporated water is compensated during the boiling. A glass sinter with a layer of quartz sand is employed by filtering. 
The concentration of acid solution suffices for the removal of starch from the cells, but the lignins, cellulose and the main part of hemicellulose remain unattacked. On the other hand it is likely, that pectins and gums are dissolved. In the writer's opinion it is not possible build up a method, by which the total of the cell wall constituents can be accurately determined: either a part of enclosure substances remains in cells or a part of the cell wall constituents are dissolved. The above described method, however, leads rather near the set aim, even though the first word of the expression "total of cell wall constituents» may not be proved quite exact, when the term is used in that meaning as in this treatise.

\begin{tabular}{|c|c|c|}
\hline & $\begin{array}{c}\text { Total of cell wall } \\
\text { constituents (by } \\
\text { the writer's } \\
\text { method) }\end{array}$ & $\begin{array}{c}\text { Crude fibre (by } \\
\text { the Weende } \\
\text { method) }\end{array}$ \\
\hline & \multicolumn{2}{|c|}{$\%$ of dry matter } \\
\hline Spruce wood $\quad \ldots \ldots \ldots \ldots \ldots \ldots \ldots \ldots \ldots \ldots$ & 90.9 & 73.8 \\
\hline Birch wood $\ldots \ldots \ldots \ldots \ldots \ldots \ldots \ldots \ldots \ldots \ldots \ldots$ & 90.8 & 59.5 \\
\hline 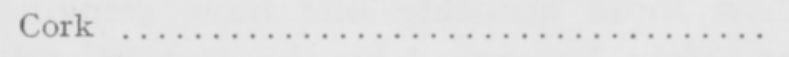 & 85.1 & 22.3 \\
\hline Peat litter $\quad \ldots \ldots \ldots \ldots \ldots \ldots \ldots \ldots \ldots \ldots \ldots \ldots$ & 85.1 & 42.9 \\
\hline Rye straw $\quad \ldots \ldots \ldots \ldots \ldots \ldots \ldots \ldots \ldots \ldots \ldots \ldots$ & 82.1 & 51.1 \\
\hline Oat straw $\ldots \ldots \ldots \ldots \ldots \ldots \ldots \ldots \ldots \ldots \ldots \ldots \ldots$ & 73.8 & 47.0 \\
\hline Oat hulls $\ldots \ldots \ldots \ldots \ldots \ldots \ldots \ldots \ldots \ldots \ldots \ldots \ldots \ldots \ldots$ & 71.6 & 34.1 \\
\hline Rye chaff $\ldots \ldots \ldots \ldots \ldots \ldots \ldots \ldots \ldots \ldots \ldots \ldots$ & 66.8 & 34.3 \\
\hline Timothy hay $\quad \ldots \ldots \ldots \ldots \ldots \ldots \ldots \ldots \ldots$ & 62.1 & 32.8 \\
\hline Timothy grass, pasture stage............. & 50.3 & 22.6 \\
\hline Red clover leaves...................... & 30.7 & 18.2 \\
\hline Wheat bran $\ldots \ldots \ldots \ldots \ldots \ldots \ldots \ldots \ldots \ldots \ldots \ldots \ldots$ & 21.5 & 9.1 \\
\hline 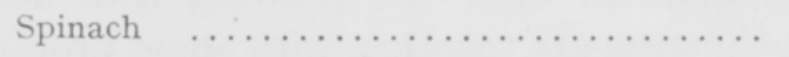 & 18.0 & 9.9 \\
\hline Mushrooms (Boletus bulbosus) ............. & 17.2 & 11.5 \\
\hline Cabbage, head, without stem $\quad \ldots \ldots \ldots \ldots \ldots$ & 14.0 & 12.6 \\
\hline Carrots $\ldots \ldots \ldots \ldots \ldots \ldots \ldots \ldots \ldots \ldots \ldots \ldots \ldots \ldots$ & 12.8 & 10.0 \\
\hline Rutabagas (Br. napus napobrassica), peeled .. & 12.7 & 10.8 \\
\hline Apples, peeled $\ldots \ldots \ldots \ldots \ldots \ldots \ldots \ldots$ & 6.3 & 5.1 \\
\hline Wheat flour, Graham ................ & 5.0 & 3.0 \\
\hline Potatoes, peeled..$\ldots \ldots \ldots \ldots \ldots \ldots \ldots \ldots$ & 3.9 & 3.0 \\
\hline Wheat flour, white $\ldots \ldots \ldots \ldots \ldots \ldots \ldots$ & 0.7 & 0.3 \\
\hline
\end{tabular}

Some figures from our investigations are exhibited in the enclosed table. It seems obvious, that the nutritive qualification of the investigated materials finds by the new method a considerable clearer expression than by the old Weende-method. 


\section{SELOSTUS.}

KETTOAINEIDEN MÄ̈̈RITT ÄMINEN RUOKA- JA REHUAINEISTA.

\section{Lauri Paloheimo.}

Yliopiston Kotieläintieteellinen laitos, Helsinki.

Raakakuitumääritys ehdotetaan korvattavaksi kettoaineiden kokonaispaljouden määrittämisellä. Menetelmä perustuu solusisällysaineiden ryhmään kuuluvien hiilihydraattien poistamiseen keittämällä näytettä 0.05 normaalisessa suolahappoliuoksessa. 